follow him in perceiving. It seems to me that in this case " the unknown quantity" is the application of his story.

I have to add that Prof. Tait's letter gives the erroneous im. pression that I have made a gratuitous assault upon his views. Contrariwise, I have said respecting them no more than is needful in self-defence. A critic who thought me greatly in need of instruction respecting the nature of proof and the warrants we have for our ultimate scientific beliefs, quoted, for my benefit, the foregoing passage from Prof. Tait; and he did this in a manner implying that when he had told me what Prof. Tait said, there remained for me no alternative but to abandon my position. As I did not coincide in his general estimate of Prof. Tait's dicta, and as this particular question is one of some philosophical interest, I thought it worth while to justify my own belief, and, in so doing, was obliged to assail that of Prof. Tait.

In Prof. Tait's desire to avoid contro versy I quite sympathise. Though sometimes scarcely avoidable, it entails, as I know too well, a grievous loss of time. But as Prof. Tait decided not to answer, I think it would have been better to keep silence absolutely, rather than to try and dispose of the matter by tearing a sentence from its context, and telling, a propos of it, a story not to the point.

Athenæum Club, March 30

Herbert Spencer

\section{Herbert Spencer versus Sir I. Newton}

PROF. TAIT is not the only one who has to complain of hard treatment in the pamphlet by Mr. Herbert Spencer, referred to in the Professor's leiter of last week. As the unlucky author of the obnoxious criticism that gave rise to the pamphlet in question, I of course come in for a lion's share of the abuse; but neither Prof. Tait nor myself are, after all, treated so cruelly as is Newton, who, though his life was spent in maintaining the experimental character of all physical science, is cited as an authority for the $\grave{a}$ priori character of the most important of all physical truths--the well-known Three Laws of Motion.

Mr. Spencer had asserted that these Laws of Motion are is priori truths, and had supported this statement by alleging that Newton gave no proot of them, and therefore intended them to be so regarded. After sheltering myself under the authority of Professors Tait and Thomson, I answered that "the whole of the Prircipia was the proof," whereon Mr. Spencer replies as follows :-

"I have first to point out that here, as before, the reviewer escapes by raising a new issue. I did not ask what he thinks about the Principia and the proof of the laws of motion by it ; nor dicl I ask whether others, at this day, hold the assertion of these law's to be justified mainly by the evidence the solar system affords. I asked what Newton thought. The reviewer had represented the belief that the second law of motion is knowable $i \overrightarrow{\text { prior }} i$ as too absurd even for me openly to enunciate. I pointed out that since Newton enunciates it openly under the title of an axiom, and offers no proof whatever of it, he did explicitly what I am blamed for doing implicitly. And thereupon I invited the reviewer to say what he thought of Newton. Instead of answering, he gives me his opinion to the effect that the laws of motion are proved true by the truth of the Principia deduced from them. Of this hereafter. My present purpose is to show that Newton did not say this, and gave every indication of thinking the contrary. He does not call the laws of motion 'hypotheses ;' he $c$ ilils them 'axioms.' He does not say that he assumes them to be true provisionally, and that the warrant for accepting them as actually true will be found in the astronomically-proved truth of the deductions. He lays them down just as nuathematical axioms are laid down--posits them as truths to be accepted $d$ priori, from which follow consequences which must therefore be accepted. And though the reviewer thinks this an untenable position, I am quite content to range myself with Newton in thinking it a tenable one-if, indeed, I may say so withost undervaluing the reviewer's judgment.'

To the sneer in the last sentence, and the remark that follows to the effect that the reviewer had evaded an issue "which it was inconvenient for him to meet," I shall reply by recommending Mr. Spencer to dogmatise either less elaborately or less rashly about the views of a philosopher like Sir I. Newton, whose works are so accessible and whose style is so clear, and at once pass on to call his attention to two passages in Newton's letters to Roger Cotes, who was at the time superintending the printing of the Principia.

In speaking of the special sense in which he used the word "hypothesis"- a sense which quite justified him in saying of himself "hypotheses non fingo"--Newton says :-

"In experimental philosophy it is not to be taken in so large a sense as to include the first Principles or Axiomes which I call the laws of Motion. These Principles are deduced from phenomence and made general by Induction, zuhich is the highest evidence that a Proposition can have in this Philosophy." (Letter lxxxi., edited by Edleston.)

And in the next letter he says :-

"On Saturday last I wrote to you representing that Experimental philosophy proceeds only upon Phenomena and deduces general Propositions from them only by Induction. And such is the proof of mutual attraction. And the arguments for $y^{\mathrm{e}}$ impenetrability, mobility, and force of all bodies, and for the lawes of motion are no better."

I must confess to feeling a difficulty in reconciling the above extracts with the view that Newton posits the laws of motion "as truths to be accepted a priori."

ThE AUthor OF THE ARticle in THE

\section{BRITISIX QUARTERLY REVIEW.}

\section{An Experiment on the Destructive Effect of Heat upon} the Life of Bacteria and their Germs

I RECENTLY carried out an experiment which I shall not soon have the opportunity of repeating, and which I am consequently anxious to put on record. It is probably now familiar to those interested in the matter, that the experiments of Dr. Sanderson have established the fact that in an infusion of turnips and cheese prepared as directed by Dr. Bastian, heating to a temperature of $102 \mathrm{C}$. is sufficient to prevent the subsequent development of life (Bacteria) in the infusion even when the exposure to that temperature is only maintained for a few minutes. Boiling for five or ten minutes, according to Dr. Sanderson, is not sufficient to prevent the subsequent development of Bacteria, but according to the experiments of Dr. Pode and myself, boiling for ten minutes or a quarter of an hour is sufficient, provided that care has been taken to exclude visible lumps of cheese, and when the infusion is enclosed in a tube which tube is submerged in boiling water. Further, Dr. Sanderson has stated the following most important result, namely, that exposure to the boiling temperature $\left(100^{\circ} \mathrm{C}\right.$.) was in all cases sufficient to prevent the subsequent development of Bacteria if it was carried on for so long as one hour.

This being the case, it occurred to me that since in all probability Bacteria and their germs, or spores, are killed by through-heating to a temperature a little below $70^{\circ} \mathrm{C}$. (as established by various experiments in regard to Bacteria, but not in regard to possible germs, and admitted by both sides in the controversy as to their biogenetic or abiogenetic origin), it is desirable to recognise in our experiments the two distinct factors of this through-heating to any given temperature-namely, (I) the temperature to which the infusion to be heated is to be exposed; and (2) the length of time during which it is exposed to that temperature. If one of these variables - the time- be taken as a horizontal, and this line be divided into equal spaces representing periods of five minuteswhilst the perpendicular represents the range of temperature divided into degrees from $65^{\circ} \mathrm{C}$. to $120^{\circ} \mathrm{C}$-and if the results of observations with a given infusion indicating the time of exposure to a particular degree of temperature required in order to prevent the subsequent devclopment of Bacteria be marked off on such a scheme, we should expect to obtain a series of points defining an asymptotic curve, the time required at the highest temperature being infinitely small, and at the lowest temperature infinitely great. This curve would vary in its character according to the properties of the infusion made use of. It was my intention to determine the principal points in this curve for Dr. Bastian's turnip and cheese infusion, but at present I have only made a tentative experiment at a low temperature. Using tubes of quarter-inch bore and three inches in length half filled with Dr. Bastian's infusion, and then submerged in water maintained at the desired temperature, I found that exposure for six hours to a temperature of $75^{\circ} \mathrm{C}$. was sufficient to prevent the subsequent development of Bacteria. The same infusion enclosed in a similar tube and not heated at all, teemed with living Bacteria after four days; the same infusion boiled for ten minutes in an open tube remained barren. I submit this plan for a series of experiments to the readers of NATURE, without attaching mnch importance to the single but definite result which is above recorded. 